\title{
PENGARUH MEKANISME SCREENING, PEMBERIAN INSENTIF DAN HUBUNGAN SOSIAL BANK DENGAN NASABAH DALAM MENGURANGI MASALAH AGENCY KREDIT PADA BANK PERKREDITAN RAKYAT DI INDONESIA
}

\author{
R. Agus Basuki \\ Fakultas Ekonomi, Universitas Islam Indonesia \\ e-mail: agusbasuki_ptp@yahoo.co.id
}

\begin{abstract}
The aims of this study are to examine (1) the performance of credit customer attribute screening, (2) the performance of credit project attribute screening, (3) the performance of incentive giving in form of credit payment motivation, (4) the performance of giving program in form of credit facility, (5) Bank social relationship program through customers, (6) the impact of credit customer attribute screening, project attribute, credit payment motivation, lending credit facility, and Bank social relationship program through customers in decreasing credit agency problem at BPR in Indonesia. The sample determinations were conducted by using simple random sampling technique. It means that samples were taken from the population of BPR credit customers randomly and all population members were given the chance to be a sample. The totals of samples were 142. Data were analyzed by using regression analysis technique. The result of this analysis shows that: first, the research variable which can affect the decreasing number of credit agency in $B P R$ in this research is the variable of motivation program to pay credit in form of giving reward to the customers who paid on time and variable of lending facility program in form of giving the low interest for the next credit. Second, the research variable which does not affect to the decreasing number of agency problem is variable of credit project attribute screening in form of customer's guarantee. Variable of credit customers attribute screening in form of his guarantee and variable of Bank social relationship program through customers in form of reminding through telephone to pay installment. Third, there is significance affect of project attribute screening, credit customers attribute screening, lending facility program and Bank social relationship program through customers in decreasing credit agency problem in BPR in Indonesia.
\end{abstract}

Keywords: credit agency, incentive, screening mechanism, social relationship, customers.

\begin{abstract}
Abstraksi
Tujuan penelitian ini adalah untuk mengkaji penerapan screening atribut nasabah kredit dalam mengurangi masalah agensi kredit pada BPR di Indonesia. Kedua, mengkaji penerapan screening atribut proyek kredit dalam mengurangi masalah agensi kredit pada BPR di Indonesia. Ketiga, mengkaji penerapan pemberian insentif berupa program motivasi pelunasan kredit dalam mengurangi masalah agensi kredit pada BPR di Indonesia. Keempat, mengkaji penerapan pemberian insentif berupa program pemberian fasilitas pinjaman (kredit) kembali dalam mengurangi masalah agensi kredit pada BPR di Indonesia. Kelima, mengkaji Program hubungan sosial bank terhadap nasabah dalam mengurangi masalah agensi kredit pada BPR di Indonesia. Keenam, mengkaji pengaruh screening atribut nasabah kredit, atribut proyek, pemotivasian pelunasan kredit, fasilitas pinjaman (kredit) kembali dan hubungan sosial bank dengan nasabah dalam mengurangi masalah agensi kredit pada BPR di Indonesia. Penentuan sampel dilakukan dengan menggunakan teknik simple random sampling. Jumlah sampel yang diperoleh sebanyak 142. Data dianalisis dengan menggunakan teknik analisis regresi. Hasil analisis menunjukkan bahwa Variabel penelitian yang dapat mempengaruhi berkurangnya masalah agensi pada kredit di BPR, dalam penelitian ini, adalah Variabel Program Motivasi melunasi Kredit berupa pemberian hadiah kepada nasabah yang tepat waktu melunasi kredit dan Variabel Program fasilitas pinjaman
\end{abstract}


kembali berupa pemberian bunga ringan pada kredit berikutnya. Kedua, Variabel penelitian yang tidak mempengaruhi berkurangnya masalah agensi kredit, dalam penelitian ini, adalah Variabel Screening atribut proyek kredit berupa jaminan yang dimiliki nasabah, Variabel screening atribut nasabah kredit berupa barang jaminan yang dimiliki sendiri, dan Variabel program hubungan sosial bank dengan nasabah berupa mengingatkan lewat telepon untuk membayar angsuran. Ketiga, terdapat pengaruh signifkan screening atribut proyek, screening atribut nasabah kredit, program motivasi pelunasan kredit, program fasilitas pinjaman (kredit) kembali dan program hubungan sosial bank dengan nasabah terhadap pengurangan masalah agensi dalam kredit pada BPR di Indonesia.

Kata kunci: agensi kredit, hubungan sosial, insentif, mekanisme screening, nasabah.

\section{PENDAHULUAN}

Menurut Laporan Bank Indonesia (2009) disebutkan bahwa BPR-BPR selama ini mengalami hambatan dalam penyaluran kredit yang sehat. Hal ini sebagian disebabkan oleh ketidak-jujuran nasabah penerima kredit, sementara di pihak bank (BPR) tidak memiliki tenaga ahli yang dapat mengenali dan menganalisis calon nasabah yang baik atau sehat. Data laporan Bank Indonesia (2009) menunjukkan, bahwa $61,5 \%$ portofolio kredit dialokasikan kepada kredit modal kerja, 35\% untuk kredit konsumtif dan 3,5\% untuk kredit investasi.

Kredit investasi menurut Hadinoto (2003) adalah kredit jangka menengah/panjang yang bertujuan membiayai barang-barang modal dalam rangka rehabilitasi, modernisasi, perluasan ataupun pendirian proyek baru. Nantinya pelunasan kredit yang diberikan berdasarkan dari hasil usaha dengan barangbarang yang dibiayai. Selanjutnya Hadinoto (2003) merinci ciri-ciri kredit investasi sebagai berikut: (1) maksimum jangka waktu kredit adalah 15 tahun, dengan masa tenggang maksimum 4 tahun, (2) kredit yang diberikan oleh bank sebesar 65\%, dan (3) suku bunga $19 \%$ per tahun.Berdasarkan kriteria tersebut di atas, maka Widianto (2007) menegaskan mengapa kredit investasi portofolionya lebih kecil dibandingkan dengan skem kredit yang lainnya.

Disamping itu, Widianto (2007) juga menjelaskan, bahwa: "Nasabah kredit diberi kekuasaan oleh bank untuk meralisasikan tujuan kontrak kredit, dan sudah sewajarnya bila nasabah bertindak mengambil keputusan terbaik dalam rangka mencapai tujuan kredit sesuai dengan kepentingan para pemilik dana". Namun demikian, tidak selamanya seorang nasabah akan bertindak sesuai dengan tujuan utama pemberian kredit tersebut. Hal ini tidak dapat dilepaskan dari motivasi kepentingan nasabah secara pribadi dalam usaha yang dilakukan. Kondisi seperti itu sering memunculkan ketegangan atau konflik kepentingan antara dua belah pihak, yaitu pihak pemilik dana (bank) dan pihak nasabah, yang biasa disebut agency problem.

Kredit adalah kontrak hutang piutang atau kerjasama antara pihak yang memiliki dana (kreditor) dengan pihak yang meminjam (debitor). Dalam kontrak seperti ini sangat mungkin timbulnya penyembunyian informasi dari satu pihak terhadap pihak lain, yang berakibat pada munculnya kredit bermasalah. Kredit bermasalah merupakan salah satu bentuk dari masalah agency dalam kontrak kredit.

Masalah agensi dalam kontrak kredit sangat menarik bagi para peneliti. Namun demikian, penelitian pada sistem perbankan biasanya hanya dilakukan pada pengelola bank. Oleh karena itu, kebaruan penelitian ini memiliki perbedaan dan keunggulan dibandingkan dengan penelitian sebelumnya, yakni dengan menelusuri data-data yang berpotensi menimbulkan terjadi masalah agensi yang langsung dikenakan kepada para nasabah kredit

\section{KAJIAN PUSTAKA DAN PENGEMBANGAN HIPOTESIS}

Menurut tujuan penggunaannya, kredit dapat dibedakan menjadi dua, yaitu (1) kredit konsumtif dan (2) kredit produktif (Firdaus dan Ariyanti, 2003). Selanjutnya dijelaskan, bahwa kredit produktif dibagi menjadi tiga, yaitu: (1) kredit investasi, (2) kredit modal kerja, dan (3) kredit likuiditas.

Sesuai dengan topik penelitian ini, yang dimaksud dengan kredit investasi adalah 
kredit yang digunakan untuk membiayai pembelian barang-barang modal tetap dan tahan lama, seperti mesin-mesin, bangunan pabrik, tanah, kendaraan, dan sebagainya (Firdaus dan Ariyanti, 2003). Kredit produktif ini memegang peranan penting bagi pertumbuhan ekonomi, baik di negara maju maupun negara sedang berkembang. Secara umum kredit investasi ditujukan untuk pendirian (pabrik) baru, modernisasi, rehabilitasi atau memperluas perusahaan. Kredit investasi biasanya berjangka panjang atau sekurangkurangnya berjangka menengah.

Kontrak kredit merupakan salah satu bagian transaksi keuangan. Kesepakatan kontrak kredit yang menjadi hukum tersebut membawa beberapa implikasi, di antaranya: (1) Nasabah sebagai orang yang dipercaya; (2) Nasabah sebagai Wakil; dan (3) Nasabah sebagai Mitra dalam keuntungan (Saeed, 1996). Dalam kontrak kredit ini, jika dikaitkan dengan teori keuangan, merupakan kontrak keuangan yang sangat berhubungan dengan masalah agensi yang berbentuk asymmetric information. Masalah ini muncul karena, kontrak kredit sangat memungkinkan agent (nasabah) melakukan penyimpangan-penyimpangan keuangan hasil proyek yang dijalankan.

Sebagaimana dikatakan oleh Benston dan Kaufman (1995), bahwa jika kredit yang diberikan oleh bank terlalu berlebihan maka dapat menimbulkan kesulitan dalam pengendalian. Lebih-lebih kontrol terhadap nasabah kredit akan sulit dilakukan. Jika hal ini terjadi maka sangat berpotensi timbulnya kredit bermasalah. Disamping itu, kontrol yang tidak ketat dapat menimbulkan terjadinya masalah agensi, baik dalam bentuk adverse selection maupun moral hazard.

Hasil penelitian Muhammad (2006) menyimpulkan bahwa atribut proyek yang perlu di-screening dalam pemberian pembiayaan mudharabah atau kredit pada umumnya adalah perlu mencermati lima aspek tersebut, yaitu: aspek kesehatan proyek, jaminan pembayaran, prospek proyek, laporan keuangan proyek, perysratan konrak dan waktu kontrak harus jelas. Pencermatan atas aspek-aspek tersebut dapat mengurangi terjadinya masalah agency dalam pembiayaan mudharabah.

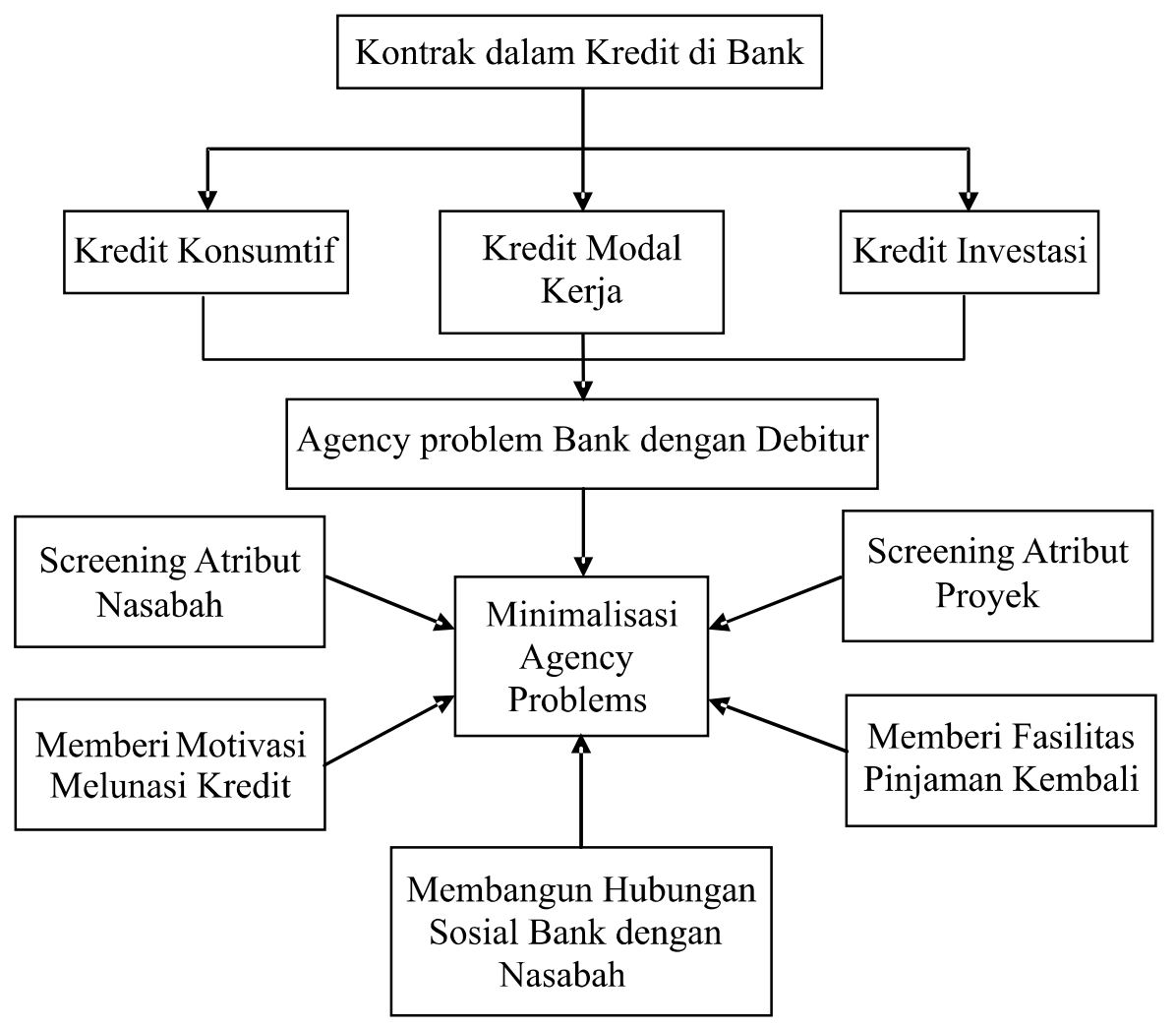

Gambar 1: Masalah Agency Kredit di Bank 
Dalam merumuskan hipotesis ini, dilakukan eksplorasi implikasi teoritis dalam merancang kontrak dan membuat keputusan untuk menerima atau menolak. Di dalam disertasi ini juga diidentifikasi faktor-faktor kunci dalam pelaksanaannya. Ada dua varian ekspektasi yang perlu dipertimbangkan, yaitu: (1) agency contracting cost expectation, dan (2) the governance structure expectation.

Varian yang berkaitan dengan the agency contracting cost expectation menggambarkan tentang keadaan, bahwa kontrak kredit sangat rentan menimbulkan masalah agency-contractual dan berhubungan dengan biaya. Dalam hal ini, masalah adverse selection dan moral hazard merupakan hal yang berpengaruh terhadap mekanisme angsuran kredit di BPR.

Teori agency yang baku mengatakan bahwa ada hubungan positif antara tingkat masalah agency dengan besarnya informasi asymetrict dalam kontrak. Dalam hal ini, Khalil et.al (2000) mengatakan, bahwa "the asymmetric information is inherent in investment contract”. Artinya: informasi tidak simetrik merupakan bagian yang melekat dalam kontrak investasi. Dua bentuk informasi asimetri, yaitu: adverse selection dan moral hazard dapat terjadi dalam kontrak kredit di bank.

Dari hasil analisis deskriptif Khalil et.al (2000), menunjukkan bahwa atribut proyek: Sistem informasi akuntansi (pelaporan); tingkat return proyek; tingkat risiko proyek; biaya pengawasan; kepastian hasil dari proyek; klausul kesepakatan proyek; jangka waktu kontrak; arus kas perusahaan; jaminan yang disediakan; tingkat kesehatan proyek; prospek proyek. Dari atribut-atribut tersebut yang memiliki nilai rata-rata di atas 0,5 meliputi atribut: kesalahan pelaporan hasil dari pelaku proyek; ketidakpastian hasil; tingkat risiko proyek; biaya pengawasan. Selanjutnya Khalil et.al (2000) menyarankan atribut tersebut dapat dipertimbangkan sebagai langkah preventif dalam mengadopsi kontrak kredit.

Saran Khalil et.al (2000) kemudian diuji oleh Sumianto (2004) pada Lembaga Keuangan (Koperasi) di Yogyakarta, hasil penelitiannya menyimpulkan, bahwa atribut proyek yang berkaitan dengan: sistem informasi akuntansi; jaminan; prospek proyek; klausul kontrak dan risiko usaha, merupakan atribut yang menentukan yang sangat diperhatikan nasabah dalam meminimalkan masalah agensi pada kontrak kredit.

Hasil penelitian di Indonesia yang dilakukan oleh Muhammad (2006) menyimpulkan bahwa atribut proyek yang perlu discreening dalam pemberian pembiayaan mudharabah - atau kredit pada umumnya adalah perlu memperhatikan faktor: (1) kesehatan proyek, (2) jaminan pembayaran, (3) prospek proyek, (4) laporan keuangan, (5) persyaratan kontrak dan (6) waktu kontrak. Pencermatan atas aspek-aspek tersebut dapat mengurangi terjadinya masalah agency dalam pembiayaan mudharabah.

H1: Screening atribut proyek berpengaruh negatif terhadap masalah agency kredit pada BPR di Indonesia

Reputasi (kompetensi dan integritas) pengusaha merupakan hal yang dipertimbangkan secara potensial berpengaruh pada timbulnya dan penentuan harga kontrak kredit. Menurut Presley dan Abalkhail (2000) bahwa pertimbangan mengenai reputasi diprediksikan akan sangat penting dalam membangun dan menetapkan kontrak kredit. Peran pengusaha dalam kontrak kredit dan karenanya kreasi nilai melalui proses berusaha, tampaknya menjadi penting dimana pengusaha menggunakan kemampuannya (bakat, skills, pengalaman, kepintaran, kepemimpinan dan lain-lain) untuk mengkombinasikan dan menggunakan aset yang riil dan tidak riil secara efektif dalam cara yang tidak mudah ditiru. Dalam kontrak kredit, kualitas personal (misalnya kejujuran) dan berbagai karakteristik pengusaha merupakan kriteria yang vital dalam hal keputusan diterima atau ditolaknya (proyek tertentu) oleh pemberi dana.

Dalam konteks ini, bank akan memperkecil masalah moral hazard yang berhubungan dengan aksi agent dan juga akan mempengaruhi pada reliabilitas laporan nasabah pada masa setelah kontrak. Hasil penelitian Khalil et.al (2000), menunjukkan bahwa reputasi, pengalaman dan kualifikasi, catatan keuangan, posisi arus keuangan, sebagai variabel yang memiliki ranking berurutan untuk dijadikan atribut nasabah (entrepreneur).

Selanjutnya, pertimbangan reputasi pengusaha diprediksikan menjadi aspek yang amat penting dalam penyusunan dan penentuan 
besarnya jumlah/nominal kontrak kredit. Sifat kewirausahaan dalam kontrak menjadi aspek penting. Dalam kontrak kredit pengusaha mencurahkan keahliannya (bakat, keterampilan, pengalaman, kepemimpinan, dsb) yang dikombinasikan dengan aset keuangan, sehingga tidak dapat dengan mudah ditiru oleh pihak lain. Dengan kata lain, dalam kontrak kredit kualitas personal dan karakteristik pengusaha merupakan kriteria penting dalam hubungannya keputusan untuk menerima atau menolak bagi pemberi dana. Aspek kualitas personal nasabah yang dapat dipertimbangkan untuk menerima nasabah sebagai agen dalam kontrak kredit menurut Presley dan Abalkhail (2000) adalah aspek skill, reputation, dan origins. Tiga aspek tersebut disebutnya sebagai faktor. Lebih jauh Presley dan Abalkhail menganalisis ketiga faktor tersebut menjadi sub faktor sebagai berikut: Faktor skill (keterampilan), meliputi: keakraban terhadap pasar; mampu mengoreksi risiko bisnis; mampu melakukan usaha yang berkelanjutan; mampu mengartikulasikan bahasa bisnis. Faktor Reputasi, meliputi: trackrecord baik sebagai karyawan; memiliki trackrecord baik sebagai pengusaha; direkomendasikan oleh sumber terpercaya; dapat dipercaya; memiliki jaminan usaha. Faktor asal-usul (origin), meliputi: memiliki hubungan keluarga atau persahabatan dengan investor; sebagai pebisnis yang sukses; berasal dari kelas sosial terpandang.

Studi yang dilakukan Sumianto (2004) berkaitan atribut nasabah yang diperhatikan oleh koperasi untuk mengurangi masalah agensi kontrak kredit adalah: keakraban nasabah terhadap pasar; kemampuan mengartikulasikan bahasa bisnis; rekomendasi pihak penjamin; barang jaminan yang dimiliki nasabah; trackrecord nasabah; usaha milik sendiri; kemampuan membuat laporan keuangan; usaha memiliki usaha yang prospek (berkembang).

Hasil di Indonesia yang dilakukan oleh Muhammad (2006) menyimpulkan bahwa atribut proyek yang perlu di-screening dalam pemberian pembiayaan mudharabah - atau kredit pada umumnya - adalah perlu memperhatikan faktor: (1) kemampuan bisnis mudharib, (2) jaminan, (3) respon pasar, (4) keluarga pebisnis, dan (5) komitmen usaha. Pencermatan atas aspek-aspek tersebut dapat mengurangi terjadinya masalah agency dalam pembiayaan mudharabah.
$\mathrm{H} 2$ : Screening atribut nasabah berpengaruh negatif terhadap masalah agency kredit pada BPR di Indonesia

Pendekatan kedua dalam pemberian kredit adalah pendekatan the governance structure expectation. Pendekatan ini memperkirakan pemantauan terhadap kontrak kredit yang akan memunculkan biaya agensi yang tinggi. Namun, jika governance structure dalam kontrak kredit kuat (robust) dapat dijadikan petunjuk dalam melakukan hubungan kontraktual dan dapat menanggulangi masalah agencycontractual dalam pemberian kredit. Wilson (1991) mengatakan bahwa kompleksitas governance structure tergantung pada hazard transaksi. Selanjutnya Wilson (1991) menegaskan "debt contractual governance that operates through rules, is a relatively simple governance compared to equity".

Ciri utama kontrak kredit di BPR membutuhkan penstrukturan efficient-cost dalam sistem contractual governance yang dapat mengurangi tingginya masalah idiosyncratic agency. Dari hasil penelitian Khalil et.al (2000), yang termasuk masalah-masalah idiosyncratic agency adalah: ketidak jujuran dan ketidak tepatan dalam memberikan bagi hasil sesuai dengan nisbah; masalah kembalinya modal yang dipinjamkan. Sehubungan dengan itu, Khalil et.al (2000) menyarankan, bahwa jika dilakukan sebelumnya, maka efisiensi contractual governance dapat dicapai dengan melakukan konstruksi mekanisme insentive yang sesuai yaitu dengan memberikan hadiah dan membagi risiko secara efisien. Sementara jika setelah kejadian, maka struktur perjanjian dapat dilakukan dengan memberikan/melengkapi informasi untuk pemantauan, kontrol, verifikasi dan penerapan incentive compatible contraints dalam hubungan kontrak kredit.

Diasumsikan bahwa permintaan terhadap monitoring service tinggi dan lebih kritis dalam kontrak kredit daripada dalam kontrak keuangan lain. Jensen dan Meckling (1976) berargumen bahwa berbagai masalah agensi yang diasosiasikan dengan kontrak keuangan dapat dikurangi dengan pengeluaran (biaya untuk) monitoring.

Di sisi lain, hasil penelitian Dharmawangsa (2003) yang dilakukan dengan pendekatan studi kasus di BPR menunjukkan, bahwa incentive compatible constraint dapat 
dilakukan dengan menciptakan mekanisme pengembalian kredit melalui instrumen Rekening Risiko dan pengumpulan harian. Instrumen ini efektif memberikan early warning system yang dapat memperkecil kemungkinan munculnya tingkat kerugian yang lebih besar pada kredit yang sedang berjalan.

Berbagai gambaran kontrak kredit di atas mengharuskan dibangunnya sistem pengaturannya kontrak yang efisien, yang dapat mengurangi berbagai masalah agensi idiosyncratic yang tinggi. Pengaturan kontrak yang efisien secara ex-ante mungkin dicapai dengan membangun mekanisme incentive yang tepat bagi pemberian reward dan penyebaran risiko secara efisien. Struktur pengaturan kontrak yang ex-post (setelah) mungkin digunakan untuk menyediakan informasi yang bermanfaat bagi proses monitoring, pengontrolan, memverifikasi dan mengimplementasikan relasi kontraktual. Hal ini dapat dicapai dengan mengaplikasikan mekanisme dari berbagai pendekatan yang berbeda dari literatur kontrak agensi yang dibahas diatas agar tersedia satu pendekatan yang hybrid. Hadinoto (2003) menawarkan sistem cara tepat untuk mengendalikan tingginya NPL bank (sehingga dapat mengurangi terjadinya masalah keagenan/agency problems), yaitu dengan cara sebagai berikut: (1) klasifikasi kolektabilitaas pinjaman dan pembentukan cadangan penghapusannya, (2) rasio-rasio dan kriteria "danger signal", (3) pengawasan dan pembinaan kredit secara berjenjang, dan (4) adanya insentif/reward bagi nasabah yang mengangsur dengan tepat waktu.

Kredit BPR yang berkategori kredit jangka menengah/panjang yang bertujuan membiayai barang-barang modal dalam rangka rehabilitasi, modernisasi, perluasan ataupun pendirian proyek baru. Pelunasan kredit ini diberikan berdasarkan dari hasil usaha dengan barang-barang yang dibiayai. Menurut Hadinoto (2003) kredit investasi dicirikan sebagai berikut: (1) maksimum jangka waktu kredit adalah 15 tahun, dengan masa tenggang maksimum 4 tahun, (2) kredit yang diberikan oleh bank sebesar 65\%, dan (3) suku bunga $19 \%$ per tahun.

Keberhasilan kredit di BPR sangat ditentukan oleh faktor-faktor yang mempengaruhi. Menurut Salam (2008) menjelaskan bahwa kunci keberhasilan kredit sangat ditentukan oleh: "nasabah pinjaman yang baik diberikan motivasi untuk melunasi pinjamannya dan didorong meminjam kembali untuk memenuhi kebutuhannya. Sedangkan peminjam yang tidak membayar pinjamannya tidak akan diberi pinjaman lagi.“

Pola di atas menggambarkan bahwa adanya motivasi dari pihak bank kepada nasabah untuk melunasi kreditnya, dan jika telah lunas akan diberikan pinjaman kembali merupakan cara yang cukup efektif dalam manajemen kredit. Pola ini dapat juga disamakan dengan pola tanggung renteng dalam pemberian kredit. Hal ini dapat dilakukan oleh para pengelola BPR dalam rangka meminimalisasi masalah agensi pada kredit yang diberikan kepada nasabah.

Selain cara-cara yang dilakukan di atas, Robinson (2002) dan Salam (2008) menemukan cara lain untuk menjadikan kredit yang diberikan bank (BPR) memiliki kinerja kredit yang baik. Robinson (2002) menyimpulkan bahwa keberhasilan kredit usaha pedesaan salah satunya ditentukan oleh "diberikan fasilitas untuk meminjam kembali". Pola ini ternyata dapat menjadi kunci keberhasilan bank dalam memberikan kredit. Kredit yang berhasil menunjukkan kecilnya masalah agensi pada kredit tersebut.

H3: Program motivasi melunasi kredit berpengaruh negatif terhadap masalah agency kredit pada BPR di Indonesia

Widianto (2007) melihat aspek pemberian fasilitas untuk kredit kembali, karena nasabah peminjam selalu tertib dalam memberikan angsuran kreditnya, sehingga dapat memperkecil terjadinya NPL bank. Lebih lanjut Widianto (2007) menegaskan, oleh karena nasabah selalu tertib dalam mengangsur kreditnya maka pihak bank memberikan fasilitas khusus bagi nasabah kredit tersebut dengan adanya reward, yaitu diberikan kemudahan dalam mengambil kredit kembali.

Dengan diketahuinya, karakter baik nasabah dan kemudian diberikan fasilitas kredit kembali akan memberikan return yang meningkat bagi Bank. Sebab, nasabah yang diberikan fasilitas kredit kembali adalah terpilih dari awal yang selama ini dinilai baik dalam mengelola kredit. Keadaan ini akan mendorong tinggi tingkat ROI kredit yang disalurkan bank (Prasetyo, 2008). 
H4: Program fasilitas pinjaman kembali berpengaruh negatif terhadap masalah agency kredit pada BPR di Indonesia

Dikatakan oleh Martowijoyo (2001) kinerja Lembaga Keuangan Pedesaan (LKP) sebagai salah satu bentuk LKM sangat ditentukan oleh dua faktor utama, yaitu faktor indogen dan faktor eksogen. Lebih lanjut ditegaskan variabel eksogen yang mempengaruhi kinerja LKP adalah hubungan sosial (HUBSOS) yang merefleksikan derajat keeratan hubungan antara pengurus LKP dengan anggota.

Menurut Nugroho (2001), keeratan hubungan antara pengelola bank dengan nasabah, merupakan cara yang paling efektif untuk mengurangi masalah agency kredit. Semakin erat hubungan pengelola bank dengan nasabah, berarti ada rasa sungkan (bhs= jawa) nasabah untuk menipu pengelola bank. Hal ini berarti nasabah akan mengangsur kreditnya dengan tepat waktu. Terlebih lagi, jika pejabat bank menggunakan pendekatan agama, yaitu pejabat bank menyampaikan kepada nasabah bahwa bila nasabah menunda pembayaran angsuran kreditnya berarti nasabah tersebut tidak amanah. Tindakan tidak amanah menurut agama adalah perbuatan yang dinilai dosa.

Sementara Salam (2008) menegaskan bahwa pengaruh hubungan sosial terhadap akses pelayanan adalah bahwa tingkat hubungan sosial lebih kuat dan signifikan pada LKP yang mempunyai intensitas tinggi dalam memobilisasi tabungan sukarela. Lebih lanjut dikatakan, hubungan sosial yang terjadi pada proses menabung lebih kuat dibandingkan pada proses perkreditan, karena adanya perasaan derajat di antara para nasabah dengan petugaas LKP. Sedangkan pengaruh signifikan hubungan sosial terhadap berkurangnya penunggak membuktikan bahwa ikatan sosial menumbuhkan dorongan untuk saling menjaga kepercayaan, membatasi konflik, dan menjaga kesinambungan hubungan ekonomi.

Hasil penelitian Nugroho (2001) menyimpulkan bahwa "beberapa rentenir menggunakan pendekatan yang lebih rasional ketika menghadapi masalah sosial-budaya". Dengan cara demikian, maka “... ekstraksi profit dari nasabahnya dengan bunga yang tinggi dikemas dalam konteks kultur hubungan baik dengan nasabah dengan mengindahkan kepedulian sosial". Hal ini dilakukan agar masalah keterlambatan membayar hutang dapat dikurangi. Dengan kata lain, rentenir bersandar pada rasionalitas instrumental ketika berbisnis, namun menggunakan rasionalitas nilai ketika berinteraksi dengan nasabah-nasabahnya. Hal ini sesuai dengan ungkapan Jawa, bahwa: "Huruf Jawa kuwi mati nek dipangku" atau "Huruf Jawa itu akan mati jika dipangku". Artinya, jika pejabat bank dapat melakukan hubungan sosial yang baik dengan nasabah, maka nasabah tersebut tidak akan melakukan kecurangan.

Pranadji (2006) menyimpulkan dalam penelitiannya bahwa aspek kerpecayaan atasu trust menjadi komponen utama pembentuk modal sosial di pedesaan. Aspek lain seperti kerjasama dan jaringan kerja tidak akan terbentuk dengan mantap jika tidak dilandaskan pada terbentuknya hubungan saling percaya antar anggota masyarakat. Pada masyarakat yang memiliki kontradiksi sosial relative tinggi, maka jaringan kepercayaan yang terbentuk umumnya sempit. Sebaliknya, pada masyarakat yang berpeotensi cepat maju umumnya mampu mengembangkan jaringan kepercayaan yang relatif besar.

Brata (2004) menemukan dalam penelitiannya, bahwa modal sosial telah membuka jalan untuk jaringan sosial yang ada dan bermanfaat dalam memperoleh bantuan atau pinjaman yang bersifat informal, ketka bantuan formal dari pemerintah sangat terbatas. Modal sosial yang mereka miliki telah menciptakan nilai ekonomi bagi dirinya.

Berdasarkan penelitian-penelitian tersebut di atas, dapat dikatakan bahwa hubungan sosial yang baik antara pihak bank dengan nasabah dapat mereduksi upaya nasabah melakukan kecurangan dalam usaha dan angsuran. Hal demikian ini dapat mengurangi terjadikan rendahnya Return on Investment (ROI) pada BPR. Dengan kata lain, masalah agensi dapat diperkecil melalui cara-cara seperti ini (membangun hubungan sosial yang baik dengan nasabah).

H5: Program hubungan sosial bank dengan nasabah berpengaruh negatif terhadap masalah agency kredit pada BPR di Indonesia

\section{METODE PENELITIAN Sampel Penelitian}

Populasi penelitian ini adalah seluruh nasabah kredit dan pengelola BPR di Indonesia. Teknik pengambilan sampel dilakukan dengan teknik 
simple random sampling. Jumlah angket yang disebar kepada nasabah berjumlah 300 yang dikirimkan kembali adalah 223 buah dan yang dapat dianalisis adalah 142 buah.

\section{Data dan Sumber Data}

Penelitian ini menggunakan data primer yang berkaitan dengan penerapan kontrak kredit. Data ini diperoleh dengan teknik wawancara, angket dan dokumentasi. Pada penelitian ini dilengkapi dengan metode survei teknik indepth interview. Pihak-pihak yang di-interview adalah nasabah, direktur BPR dan bagian Account Officer. Dari setiap bank diambil 10 orang nasabah beserta $\mathrm{AO}$ dari masing-masing nasabah tersebut. Kemudian, kadang dimintakan pula informasi-informasi tambahan yang sifatnya sebagai pelengkap pada Direktur Bank yang bersangkutan.

\section{Pengukuran Variabel}

Variabel yang dijadikan obyek studi ini adalah didasarkan pada landasan teori yang dikembangkan, yaitu:

Variabel Atribut proyek adalah ciri-ciri proyek yang diusulkan oleh nasabah dan dinilai baik oleh pihak BPR, sehingga calon proyek nasabah disepakati oleh bank untuk dibiayai dengan kontrak kredit. Sesuai dengan penelitian yang dilakukan oleh Khalil et.al (2000), Sumianto (2004), Muhamad (2006). Berdasarkan hasil penelitian tersebut, maka dalam penelitian, atribut proyek tersebut dapat diinventarisasikan sebagai berikut: (1) sistem informasi akuntansi, (2) tingkat return, (3) tingkat risiko minimal, (4) biaya pemantauan rendah, (5) kepastian hasil, (6) aturan (klausul) pengawasan, (7) jangka waktu kontrak, (8) arus kas perusahaan, (9) jaminan yang dimiliki, (10) tingkat kesehatan proyek.

Variabel Atribut nasabah adalah sifat-sifat calon nasabah yang dipertimbangkan oleh bank untuk dapat diterima atau tidaknya calon tersebut menjalankan proyek dengan kontrak kredit. Sesuai dengan hasil penelitian yang ditemukan oleh Khalil, et.al (2000), Presley dan Abalkhail (2000), Sumianto (2004), Muhamad (2006). Berdasarkan hasil penelitian tersebut, maka dalam studi ini, aspek-aspek yang dipertimbangkan bank untuk diterima atau ditolak menjalankan kontrak kredit adalah: (1) keakraban terhadap pasar, (2) kemampuan mengoreksi risiko, (3) memiliki usaha/proyek yang berkelanjutan, (4) kemampuan mengartikulasi bahasa proyek, (5) memiliki track-record baik, (6) memiliki rekomendasi pihak lain, (7) memiliki barang jaminan sendiri, (8) proyek milik sendiri, (9) status sosial nasabah, (10) berasal dari keluarga pebinis, (11) memiliki hubungan dengan investor, (12) mampu membuat laporan keuangan, (13) memiliki keahlian di bidang usahanya, (14) memiliki komitmen terhadap janji, (15) memiliki kemampuan menangkap peluang, (16) mampu membuat keputusan bisnis, (17) memiliki hubungan historis dengan bank.

Memotivasi Pelunasan Kredit adalah upaya yang dilakukan oleh pihak bank dengan mendorong nasabah kredit untuk membayar angsuran kreditnya sesuai dengan tepat waktu yang diperjanjikan. Sesuai dengan hasil penelitian yang ditemukan oleh Robinson (2002), Hadinoto (2003), Widianto (2007) dan Salam (2008). Berdasarkan hasil penelitian tersebut, maka dalam studi ini, cara memotivasi yang dilakukan bank adalah dengan (1) pemberian hadiah kepada nasabah yang melunasi tepat waktu, (2) pemotongan sekali angsuran bagi angsuran yang sebelum waktu jatuh tempo, (3) dan pengenaan denda bagi nasabah yang menunggak.

Fasilitas Pinjaman Kembali, adalah fasilitas kredit yang diberikan oleh bank kepada nasabah. Sesuai dengan hasil penelitian yang ditemukan oleh Robinson (2002), Hadinoto (2003), Widianto (2007) dan Salam (2008). Berdasarkan hasil penelitian tersebut, fasilitas pinjaman kembali dapat dilakukan dengan bentuk (1) pemberian kredit lanjutan, (2) kemudahan pengajuan dan pengambilan kredit kembali, dan (3) pemberian bunga ringan bagi kredit berikutnya.

Hubungan Sosial Bank dengan Nasabah adalah kontak setelah realisasi kredit yang dilakukan oleh bank nasabah pinjaman. Sesuai dengan hasil penelitian yang ditemukan oleh Martowijoyo (2001), Nugroho (2001), dan Salam (2008). Berdasarkan hasil penelitian tersebut, kontak ini dilakukan dengan (1) cara berkunjung kepada nasabah kredit di luar 
waktu penagihan, (2) mengingatkan waktu mengangsur melalui telepon, dan (3) pemberian penangguhan pembayaran angsuran bagi nasabah lama.

Masalah agensi kontrak kredit di BPR adalah penyimpangan-penyimpangan yang dilakukan oleh nasabah terhadap bank dalam hal pemberian return atas modal yang telah diinvestasikan atau disebut return on investment (ROI). Hal ini didasarkan pada teori yang digunakan oleh Prasetyo (2008). Pengukuran dilihat dari Return on Investment (ROI) kredit, yaitu: Tinggi, Rendah. Tinggirendahnya ROI ditentukan berdasarkan nilai rata-rata variabel ROI, jika nilai ROI di bawah nilai rata-rata seluruh sampel, maka kategorinya rendah. Jika nilai ROI di atas nilai rata-rata seluruh sampel, maka Tinggi. Jika ROI kredit rendah berarti terjadi masalah agency. Namun sebaliknya, jika ROI kredit tinggi berarti tidak terjadi masalah agency. Masalah agency diukur dari selisih antara ROI yang sesungguhnya (Actual ROI) - ROI yang diharapkan (Expected ROI).

\section{Masalah Agency $=$ Denda $=$ Actual ROI - Expected ROI}

ROI actual diperoleh dari bunga kredit ditambah dengan denda tunggakan. Dengan kata lain, agency dalam penelitian ini adalah bukan saja hasil yang kurang dalam angsuran, namun juga pendapatan yang melebihi hasil yang diharapkan sebagai akibat dari denda yang dibayar. Hal ini berarti, semakin tinggi denda maka semakin tinggi masalah agency.

\section{ANALISIS DATA}

Data sampel yang dikumpulkan dari responden melalui angket, diolah menggunakan sistem aplikasi SPSS. Teknik analisis data yang digunakan adalah dengan teknik analisis regresi. Secara teoritik model analisis regresi dapat diformulasikan sebagai berikut:

$Y_{i}=\alpha+\beta_{1} X_{1 i}-\beta_{2} X_{2 i}-\beta_{3} X_{3 i}-\beta_{4} X_{4 i}-\beta_{5} X_{5 i}$

Dengan:

$\mathrm{Y}=$ Masalah Agency Kredit Nasabah i

$\alpha=$ Konstanta

$\beta_{1} \ldots \beta_{5}=$ Koefisien regresi $X_{1} \ldots X_{5}$

$\mathrm{X}_{1}=$ Nilai Atribut Proyek Nasabah $i$

$\mathrm{X}_{2}=$ Nilai Atribut Nasabah $i$

$X_{3}=$ Nilai Pemberian Motivasi melunasi Kredit Nasabah $i$

$\mathrm{X}_{4}=$ Nilai Fasilitas Pinjaman Kembali Nasabah $i$

$\mathrm{X}_{5}=$ Nilai Hubungan Sosial Bank dengan Nasabah $i$

\section{Pengujian Hipotesis}

Berdasarkan kerangka atau model konseptual tersebut di atas, dapat diketahui bahwa kontrak kredit secara langsung memiliki implikasi akan munculnya masalah-masalah agency, yang dapat mempengaruhi struktur pengelolaan kontrak. Pada bagian ini, akan dikaji hipotesis yang berhubungan dengan kontrak kredit. Dalam merumuskan hipotesis ini, dilakukan eksplorasi implikasi teoritis dalam merancang kontrak dan membuat keputusan untuk menerima atau menolak.

\begin{tabular}{cc}
\hline Hipotesa & Ekspektasi \\
\hline Hipotesis 1 & $\beta_{1}=$ berpengaruh negatif (-) \\
Hipotesis 2 & $\beta_{2}=$ berpengaruh negatif (-) \\
Hipotesis 3 & $\beta_{3}=$ berpengaruh negatif (-) \\
Hipotesis 4 & $\beta_{4}=$ berpengaruh negatif (-) \\
Hipotesis 5 & $\beta_{5}=$ berpengaruh negatif (-) \\
\hline
\end{tabular}

\section{HASIL PENELITIAN DAN PEMBAHASAN}

Hasil analisis regresi pengaruh Atribut Proyek, Atribut Nasabah Kredit, Motivasi melunasi Kredit, Fasilitas Pinjaman Kembali, dan Hubungan Sosial Bank dengan Nasabah terhadap Masalah Agency Kredit pada BPR se Indonesia ditemukan sebagai berikut:

$$
\begin{aligned}
& A G P R O B=A-\beta_{1} X_{1}-\beta_{2} X_{2}-\beta_{3} X_{3}-\beta_{4} X_{4}-\beta_{5} X_{5} \\
& \text { Coef Reg }=0,019+0,041+0,034-0,020-0,022+0,033 \\
& \text { Coef. } \mathrm{t}=(1,171)(2,202)(2,806)(-3,358)(-2,777)(3,928)
\end{aligned}
$$

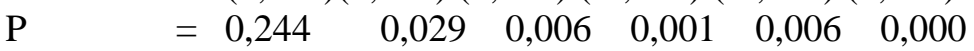

$$
\begin{aligned}
& \mathrm{F} \quad=10,359
\end{aligned}
$$

Adjusted $R^{2} \quad 0,249$ 
Keterangan:

$A G P R O B=$ Agency Problem of Credit

$\alpha=$ Constanta

$X_{1}=$ Atribut Proyek

$X_{2}=$ Atribut Nasabah Kredit

$X_{3}=$ Motivasi melunasi Kredit

$X_{4}=$ Fasilitas Pinjaman Kembali

$X_{5}=$ Hubungan Sosial Bank dengan Nasabah

Tabel 1: Hasil Anasilis Uji Asumsi Klasik

\begin{tabular}{ccc}
\hline Hipotesa & \multicolumn{1}{c}{ Ekspektasi } & Hasil \\
\hline Hipotesis 1 & $\beta_{1}=$ berpengaruh negatif $(-)$ & $\beta_{1}=$ berpengaruh positif $(+)$ \\
Hipotesis 2 & $\beta_{2}=$ berpengaruh negatif $(-)$ & $\beta_{2}=$ berpengaruh positif $(+)$ \\
Hipotesis 3 & $\beta_{3}=$ berpengaruh negatif $(-)$ & $\beta_{3}=$ berpengaruh negatif $(-)$ \\
Hipotesis 4 & $\beta_{4}=$ berpengaruh negatif $(-)$ & $\beta_{4}=$ berpengaruh negatif $(-)$ \\
Hipotesis 5 & $\beta_{5}=$ berpengaruh negatif $(-)$ & $\beta_{5}=$ berpengaruh positif $(+)$ \\
\hline
\end{tabular}

Berdasarkan hasil analisis uji asumsi klasik, dapat disimpulkan bahwa secara keseluruhan model regresi memenuhi syarat uji asumsi klasik. Relevansi model teoritik dengan model empirik dalam penelitian ini dapat disimpulkan sebagaimana tampak pada tabel 2 .

\section{Uji Koefisien Determinasi}

Hasil analisis SPSS memberikan besarnya adjusted $\mathrm{R}$ square $\left(\mathrm{R}^{2}\right)$ sebesar 0,249 . Hal ini berarti 24,9\% variasi Masalah Agency Kredit yang dapat dijelaskan oleh variabel independen Atribut Proyek, Atribut Nasabah Kredit, Motivasi melunasi Kredit, Fasilitas Pinjaman Kembali, dan Hubungan Sosial Bank dengan Nasabah. Sedangkan sisanya sebesar $75,1 \%$ dijelaskan oleh sebab-sebab lain di luar model. Adapun sebab-sebab lainnya, di antaranya adalah: kemampuan nasabah, kondisi bisnis nasabah, kebutuhan nasabah, situasi eksternal nasabah.

\section{Uji Signifikansi Kesesuaian Model}

Uji Anova atau $\mathrm{F}$ test menghasilkan nilai $\mathrm{F}$ hitung sebesar 10,359 dengan tingkat signifikansi 0,00 . Karena probabilitas signifikansi jauh lebih kecil dari pada 0,05, maka model regresi dapat digunakan untuk memprediksi Masalah Agency Kredit. Hal ini berarti, bahwa Atribut Proyek, Atribut Nasabah Kredit, Motivasi melunasi Kredit, Fasilitas Pinjaman Kembali, dan Hubungan Sosial Bank dengan Nasabah secara bersama-sama dapat digunakan untuk mengurangi terjadi masalah agency pada kredit di BPR. Dengan kata lain, ada pengaruh secara signifikan dari Atribut Proyek, Atribut Nasabah Kredit, Motivasi melunasi Kredit, Fasilitas Pinjaman Kembali, dan Hubungan Sosial Bank dengan Nasabah terhadap masalah agency kredit di BPR.

Berdasarkan hasil analisis dan uraian di atas dapat diketahui bahwa ada pengaruh secara signifikan dari Atribut Proyek, Atribut Nasabah Kredit, Motivasi melunasi Kredit, Fasilitas Pinjaman Kembali, dan Hubungan Sosial Bank dengan Nasabah terhadap masalah agency kredit di BPR. Hal ini berarti, ada dua tahap yang harus diperhatikan oleh pihak bank dalam memberikan kredit di BPR agar tidak terjadi masalah agency kredit. Tahap pertama adalah tahap sebelum (ex-ante) memberikan kredit. Pada tahap ini pihak bank harus melakukan screening atas atribut proyek yang akan diberi kredit dan atribut nasabah kredit yang akan diberi kredit. Tahap kedua adalah tahap sesudah (post-ante) memberikan kredit. Pada tahap ini, ada tiga cara yang dapat dilakukan pihak bank, yaitu: (1) memberikan motivasi kepada nasabah dalam melunasi kreditnya, (2) memberi fasilitas pinjaman kembali kepada nasabah yang telah melunasi kredit dengan lancar, dan (3) menjalin hubungan sosial bank dengan nasabah secara baik.

\section{Uji Parameter Individual (Uji t Statistik)}

\section{Pengaruh Screening Atribut Proyek terhadap masalah agency kredit}

Berdasarkan hasil analisis pengaruh screening atribut proyek terhadap masalah agency kredit ditemukan nilai koefisien parameter 2,202 
dengan tingkat signifikansi 0,029. Jadi, hipotesis penelitian yang menyatakan Screening atribut proyek berpengaruh negatif terhadap masalah agency kredit di BPR di Indonesia, tidak didukung data dengan tingkat signifikansi 0,005. Hal ini berarti, jika BPR memperhatikan atribut proyek dalam memberikan kredit, maka masalah agency semakin meningkat. Dengan kata lain, atribut proyek yang di-screening secara baik oleh pihak BPR dalam memberikan kredit maka berpengaruh terhadap peningkatan atau munculnya masalah agency kredit di BPR. Implikasi temuan ini adalah bahwa pejabat BPR tidak harus memperhatikan atribut proyek nasabah dengan baik sebelum proyek tersebut akan dibiayai agar masalah agency menurun.

Realitas yang terjadi dapat dilihat, bahwa mekanisme screening bukan menjadi sesuatu yang penting dalam analisis kredit dalam rangka untuk menurunkan masalah agency. Oleh karena itu wajar bila screening atribut proyek yang dilakukan oleh pihak bank tidak menurunkan masalah agency.

\section{Pengaruh Screening Atribut Nasabah Kredit terhadap Masalah Agency Kredit}

Berdasarkan hasil analisis pengaruh atribut nasabah terhadap masalah agency kredit ditemukan nilai koefisien parameter 2,806 dengan tingkat signifikansi 0,006. Jadi, hipotesis penelitian yang menyatakan Screening atribut nasabah berpengaruh negatif terhadap masalah agency kredit di BPR di Indonesia, tidak didukung data dengan tingkat signifikansi 0,005. Hasil penelitian ini menunjukkan, jika BPR memperhatikan atribut nasabah dalam memberikan kredit, maka masalah agency semakin meningkat. Dengan kata lain, atribut nasabah yang diperhatikan secara baik oleh pihak BPR dalam memberikan kredit maka masalah agency kredit di BPR akan terjadi semakin besar.

Secara teoritis atribut atau karakteristik nasabah yang perlu dan harus diperhatikan oleh pejabat BPR adalah berkaitan dengan: reputasi pengusaha; pengalaman dan kualifikasi pengusaha; kesalahan pelaporan hasil yang dilakukan oleh pengusaha; catatan keuangan pengusaha; dapat meng-akses informasi maka masalah agency kredit dapat diperkecil. Hasil wawancara dengan para pejabat bank (direktur dan account officer) disimpulkan, bahwa pihak bank sangat memperhatikan karakteristik nasabah untuk mengurangi terjadinya masalah agency.

\section{Pengaruh Program Motivasi melunasi Kredit terhadap Masalah Agency Kredit}

Berdasarkan hasil analisi pengaruh program motivasi melunasi kredit terhadap masalah agency kredit ditemukan nilai koefisien parameter $-3,358$ dengan tingkat signifikansi 0,001. Jadi, hipotesis penelitian yang menyatakan Program Motivasi melunasi Kredit berpengaruh negatif terhadap masalah agency kredit di $B P R$ di Indonesia, didukung oleh data. Hal ini berarti, bahwa penelitian ini menemukan, Program Motivasi melunasi Kredit berpengaruh terhadap masalah agency kredit di BPR di Indonesia. Hal ini berarti, jika pihak BPR menerapkan program motivasi melunasi kredit maka dapat mengurangi masalah agency kredit. Dengan kata lain, pihak BPR dalam memberikan kredit perlu menggunakan program memotivasi nasabah agar masalah agency kreditnya menurun. Hal ini berarti pula, semakin tinggi penggunaan program memotivasi nasabah maka semakin kecil masalah agency kredit muncul. Dengan demikian, pejabat BPR perlu menerapkan program motivasi kepada nasabah dalam penyelesaian kreditnya, sehingga masalah agency kredit dapat diturunkan.

\section{Pengaruh Program Fasilitas Pinjaman Kembali terhadap Masalah Agency Kredit} Berdasarkan hasil analisis pengaruh fasilitas pinjaman kembali terhadap masalah agency ditemukan nilai koefisien parameter $-2,777$ dengan tingkat signifikansi 0,006. Jadi, hipotesis penelitian yang menyatakan Program Fasilitas Pinjaman Kembali berpengaruh negatif terhadap masalah agency kredit di BPR di Indonesia, didukung oleh data. Dengan kata lain, penelitian memukan, bahwa Program Fasilitas Pinjaman Kembali berpengaruh terhadap masalah agency kredit di BPR di Indonesia. Hal ini berarti, jika program fasilitas pinjaman kembali diberlakukan maka masalag agency kredit dapat dikurangi. Temuan ini mengandung arti pula, jika pihak BPR menerapkan program fasilitas pinjaman kembali secara baik, maka dapat mengurangi masalah agency kredit atau masalah agency terjadi menurun atau kecil. Dengan kata lain, pihak BPR dalam memberikan kredit harus menggunakan program fasilitas pinjaman kem- 
bali kepada nasabah. Sebab, jika program tersebut diterapkan dapat mengurangi terjadinya masalah agency kredit nasabah.

\section{Pengaruh Program Hubungan Sosial Bank dengan Nasabah terhadap Masalah Agency Kredit}

Berdasarkan hasil analisis pengaruh hubungan sosial bank dengan nasabah terhadap masalah agency kredit ditemukan nilai koefisien parameter 3,928 dengan tingkat signifikansi 0,000. Jadi, hipotesis penelitian yang menyatakan Screening program hubungan sosial bank dengan nasabah berpengaruh negatif terhadap masalah agency kredit di BPR di Indonesia, tidak didukung oleh data atau ditolak dengan tingkat signifikansi 0,005 . Hal ini berarti, jika BPR memperhatikan program hubungan sosial bank dengan nasabah dalam memberikan kredit, maka masalah agency menjadi besar. Dengan kata lain, program hubungan sosial bank dengan nasabah yang diperhatikan secara baik oleh pihak BPR dalam memberikan kredit maka berpengaruh terhadap meningkatnya masalah agency kredit di BPR. Implikasinya adalah pejabat BPR tidak harus memperhatikan program hubungan sosial bank dengan nasabah setelah proyek tersebut akan dibiayai.

Hasil analisis regresi dalam penelitian ini menunjukkan bahwa variabel penelitian dapat mempengaruhi berkurangnya masalah agency pada kredit di BPR yaitu variabel program Motivasi melunasi Kredit berupa pemberian hadiah kepada nasabah yang tepat waktu melunasi kredit dan variabel Program fasilitas pinjaman kembali berupa pemberian bunga ringan pada kredit berikutnya. Kedua, variabel penelitian tidak mempengaruhi berkurangnya masalah agency kredit yaitu variabel Screening atribut proyek kredit berupa jaminan yang dimiliki nasabah, variabel screening atribut nasabah kredit berupa barang jaminan yang dimiliki sendiri, dan variabel program hubungan sosial bank dengan nasabah berupa mengingatkan lewat telepon untuk membayar angsuran. Ketiga, terdapat pengaruh signifkan screening atribut proyek, screening atribut nasabah kredit, program motivasi pelunasan kredit, program fasilitas pinjaman (kredit) kembali dan program hubungan sosial bank dengan nasabah terhadap pengurangan masalah agency dalam kredit pada BPR di Indonesia. Keempat, besarnya pengaruh screening atribut proyek, screening atribut nasabah kredit, program motivasi pelunasan kredit, program fasilitas pinjaman (kredit) kembali dan program hubungan sosial bank dengan nasabah terhadap pengurangan masalah agency dalam kredit pada BPR di Indonesia adalah sebesar 0,249. Hal ini menunjukkan sisanya sebesar $75,1 \%$ dijelaskan oleh sebabsebab lain di luar model penelitian ini.

Berdasarkan hasil analisis atau uji hipotesis ditemukan bahwa secara keseluruhan variabel pengaruh, yaitu Atribut Proyek, Atribut Nasabah Kredit, Motivasi melunasi Kredit, Fasilitas Pinjaman Kembali, dan Hubungan Sosial Bank secara bersama-sama berpengaruh terhadap pengurangan masalah agency pada kredit di BPR. Hasil ini berarti bahwa variabel Atribut Proyek, Atribut Nasabah Kredit, Motivasi melunasi Kredit, Fasilitas Pinjaman Kembali, dan Hubungan Sosial Bank dengan Nasabah dapat dijadikan sebagai prediktor terhadap upaya BPR dalam mengurangi terjadinya masalah agency pada kredit yang telah dipinjamkan kepada nasabah.

Apabila variabel Atribut Proyek, Atribut Nasabah Kredit, Motivasi melunasi Kredit, Fasilitas Pinjaman Kembali, dan Hubungan Sosial Bank dengan Nasabah dapat dijadikan sebagai prediktor terhadap upaya BPR dalam mengurangi terjadinya masalah agency pada kredit berarti variabel tersebut harus diperhatikan dan dipertimbangkan oleh para pelaku bank dalam memberikan kredit. Sebab dengan perhatian yang baik atas variabel-variabel yang mempengaruhi pengurangan masalah agency dari para pejabat BPR, maka akan menjadikan masalah agency yang akan terjadi dapat dikurangi. Berkurangnya masalah agency kredit yang terjadi akan menjadikan return of investment (ROI) yang dilakukan oleh BPR akan tinggi.

Walaupun secara keseluruhan variabel pengaruh dalam penelitian ini secara bersamasama mempengaruhi pengurangan masalah agency kredit, namun hasil pengujian secara parsial ada dua variabel yang mempengaruhi terhadap pengurangan masalah agency. Kedua variabel tersebut adalah (1) variabel motivasi kepada nasabah dalam melunasi kreditnya dan (2) variabel fasilitas pinjaman kembali kepada nasabah yang telah melunasi kredit dengan lancar. 
Mengapa kedua variabel tersebut di atas mempengaruhi terhadap pengurangan masalah agency kredit di BPR? Untuk menjawab pertanyaan ini dapat dijelaskan, bahwa munculnya masalah agency jika diterapkan program motivasi pelunasan kredit dapat dikendalikan jika pihak BPR menerapkan prioritas program motivasi pelunasan nasabah. Adapun program prioritasnya adalah (1) pengenaan keringan denda tunggakan, (2) pemotongan sekali angsuran dan (3) pemberian hadiah kepada nasabah yang tepat waktu melunasi kredit.

Hal ini sesuai dengan kesimpulan penelitian Salam (2008) yaitu: nasabah pinjaman yang baik diberikan motivasi untuk melunasi pinjamannya dan didorong meminjam kembali untuk memenuhi kebutuhannya. Sedangkan peminjam yang tidak membayar pinjamannya tidak akan diberi pinjaman lagi.

Demikian pula fasilitas pinjaman kembali terhadap pengurangan masalah agency pada kredit di BPR di Indonesia terjadi karena pihak BPR memprioritaskan menerapkan program pemberian fasilitas pinjaman kembali bagi nasabah BPR dengan urutan (1) Kemudahan mengambil kredit, (2) Pemberian kredit lanjutan, dan (3) Pemberian bunga ringan pada kredit berikutnya, maka dapat mengurangi masalah agency.

Hal ini sesuai dengan kesimpulan penelitian yang dilakukan Robinson (2002) dan Salam (2008) menemukan cara lain untuk menjadikan kredit yang diberikan bank (BPR) memiliki kinerja kredit yang baik. Robinson (2002) menyimpulkan bahwa keberhasilan kredit usaha pedesaan salah satunya ditentukan oleh "diberikan fasilitas untuk meminjam kembali”. Pola ini ternyata dapat menjadi kunci keberhasilan bank dalam memberikan kredit. Kredit yang berhasil menunjukkan kecilnya masalah agensi pada kredit tersebut.

Pertanyaan selanjutnya, mengapa variabel screening Atribut Proyek, Atribut Nasabah Kredit, dan Hubungan Sosial Bank dengan Nasabah tidak berpengaruh terhadap pengurangan masalah agency kredit di BPR. Fenomena ini dapat dijelaskan, karena banyak dikalangan BPR yang dalam memberikan kredit tidak mempedulian teori maupun pelanggaran ketentuan yang berlaku. Sebagai contoh, masalah screening proyek maupun nasabah. Masalah screening ini dilakukan oleh bank, namun hanya sebatas formalitas. Misal- nya, pejabat bank memperhatikan masalah $5 \mathrm{C}$ atau 4P dalam pemberian kredit. Namun ini tidak dianalisis denga cermat. Buktinya adalah, banyak BPR menawarkan kredit dengan proses yang sagat mudah dan cepat. Sebagaimana di bagian sebelumnya dijelaskan, bahwa banyak BPR yang mengiklankan atau memasang spanduk dengan tulisan: KREDIT SATU HARI CAIR, KREDIT BUNGA RINGAN, KREDIT DENGAN JAMINAN BPKB, dan kata-kata yang sepadan dengan itu.

Dengan demikian, maka dapat ditegaskan bahwa mekanisme screening yang selama ini dilakukan belum menunjukkan mekanisme yang sebenarnya. Sehingga dalam konteks ini screening bukan merupakan alat yang tepat untuk mengurangi terjadinya masalah agency kredit.

\section{PENUTUP}

Hasil penelitian ini menunjukkan bahwa variabel penelitian yang dapat mempengaruhi berkurangnya masalah agency pada kredit di BPR adalah Variabel Program Motivasi melunasi Kredit berupa pemberian hadiah kepada nasabah yang tepat waktu melunasi kredit dan Variabel Program fasilitas pinjaman kembali berupa pemberian bunga ringan pada kredit berikutnya. Sedangkan variabel penelitian yang tidak mempengaruhi berkurangnya maslah agency kredit, dalam penelitian ini, adalah Variabel Screening atribut proyek kredit berupa jaminan yang dimiliki nasabah, Variabel screening atribut nasabah kredit berupa barang jaminan yang dimiliki sendiri, dan Variabel program hubungan sosial bank dengan nasabah berupa mengingatkan lewat telepon untuk membayar angsuran. Hasil penelitian juga menunjukkan bahwa terdapat pengaruh signifkan screening atribut proyek, screening atribut nasabah kredit, program motivasi pelunasan kredit, program fasilitas pinjaman (kredit) kembali dan program hubungan sosial bank dengan nasabah terhadap pengurangan masalah agency dalam kredit pada BPR di Indonesia.

\section{REFERENSI}

Bank Indonesia. 2009. Laporan Bank Indonesia. Yogyakarta.

Benston, G and George G. Kaufman. 1995. "Is the Banking and payment System 
Fragile?", Journal of Financial Service Research, Vol. 9 No. $3 / 4$.

Brata, A.G., "Accessing Formal Credit: Social Capital versus 'Social Position' (Leason from a Javanese Village), http://129.3.20.41/eps/fin/ papers/0507/0507016.pdf. diakses pada tanggal 23 Januari 2004.

Dharmawangsa. 2003. "Analisis Masalah Agency pada Pembiayaan Mudharabah di BPRS Heurekah Aceh", Tesis Magister Studi Islam, Yogyakarta: Program Pascasarjana Magister Studi Islam Universitas Islam Indonesia.

Firdaus, R dan Maya, A. 2003. Manajemen Perkreditan Bank Umum: teori, masalah, kebijakan dan aplikasinya lengkap dengan analisis kredit, Jakarta: Alfabeta.

Hadinoto. 2003. Manajemen Kredit, Yogyakarta: BPFE.

Jensen, C. Michael dan W.H. Mechkling, "Theory of the Firm: managerial Behavior, Agency Costs and Ownership Structure", Journal of Fiancial Economics, No.3, 1976.

Khalil, et.al. 2000. "Agency Contractual in Profit-Sharing Financing," Islamic Finance: Challenges and Opportunities in The Twenty-First Century, Conference Papers, Fourth International Conference on Islamic Economic and Banking Loughborough University, UK, August 13-15.

Martowijoyo, S. 2001. Dampak Pemberlakuan Sistem Bank Perkreditan Rakyat dalam Kemiskinan dan Keuangan Mikro, Jakarta: Gema PKM Indonesia.

Muhamad. 2006. "Permasalahan Agency dalam kontrak Mudharabah pada Bank Perkreditan Rakyat Syariah di Indonesia”, Disertasi, Program Doktor Ilmu Ekonomi UII, Yogyakarta: FE UII.

Nugroho, H. 2001. Uang, Rentenir dan Hutang Piutang di Jawa. Yogyakarta: Pustaka Pelajar.
Pranadji, T. "Penguatan Modal Sosial untuk Pemberdayaan Masyarakat Pedesaan dalam Pengelolaan Agroekosistem Lahan kering". Jurnal Agroekonomi, Vol. 24. No. 2 Oktober 2006.

Prasetyo, B.W. 2008. "Analisis Pengaruh Struktur Modal terhadap Kinerja Bank Syariah: perspektif Agency Theory", Skripsi, Fakultas Ekonomika dan Bisnis UGM.

Presley, John, R. dan Abalkhail, M. 2000. "How Informal Risk Capital Investor Manage the Asymmetric Information in Profit-loss Sharing Contract (PLS): Lessons to be Learn by Islamic Financial Institution," Conference Papers Fourth International Conference on Islamic Economics and banking Loughborough University, UK, August 13-15.

Robinson, Marguereite S., 2000. The Microfinance Revolution: Lessons from Indonesia, Washington: The World Bank and Open Society Institute.

Saeed, A. 1996. Banking and Interest: A Study of Prohibitation of Riba and Its Contemporary Interpretation. Leiden, New York, Koln: EJ. Brill.

Salam, A. 2008. Sustainabilitas Lembaga Keuangan Mikro Koperasi Simpan Pinjam, Yogyakarta: Sekolah Pascasarjana UGM.

Sumianto, A. 2004. "Minat Manajer BMT di Yogyakarta dalam Menerapkan Produk Pembiayaan Mudharabah", Tesis, Tidak dipublikasikan, Yogyakarta: MSI UII.

Widianto. 2007. Analisis Kredit Usaha Menengah dan Kecil, Yogyakarta: Pustaka Pelajar.

Wilson, Peter W., 1991. A Question of Interest: The Paralysis of Saudi Banking, Boulder: Westview Press 